\title{
Penerapan Model Discovery Learning pada Materi Pemanasan Global untuk Meningkatkan Keterampilan Berpikir Kritis Peserta Didik
}

\author{
Novita Haryanti, Antonius Tri Widodo, Yuni Arfiani
}

(C) 2019 JEMS (Jurnal Edukasi Matematika dan Sains)

This is an open access article under the CC-BY-SA license (https://creativecommons.org/licenses/bysa/4.0/) ISSN 2337-9049 (print), ISSN 2502-4671 (online)

\begin{abstract}
Abstrak:
Penelitian ini bertujuan untuk mengetahui peningkatan keterampilan berpikir kritis peserta didik dengan menggunakan model discovery learning pada materi pemanasan global. Penelitian ini dilakukan pada kelas VII di SMP Negeri 2 Taman Pemalang tahun pelajaran 2018/2019. Pengambilan sampel penelitian menggunakan teknik multi stage random sampling dengan mengambil dua kelas dari populasi untuk kelas kontrol dan kelas eksperimen. Pengumpulan data menggunakan metode tes dengan soal uraian. Hasil penelitian menunjukkan bahwa kelas eksperimen yang menggunakan model discovery learning keterampilan berpikir kritis yang di diperoleh peserta didik meningkat. Hal ini ditunjukkan dari pada kenaikan persentase peserta didik yang mulanya $100 \%$ pada kategori kurang kritis menjadi $4 \%$ pada kategori sangat kritis, $56 \%$ kritis, 36\% cukup kritis dan $4 \%$ kurang kritis.
\end{abstract}

Kata Kunci : Discovery Learning; Keterampilan Berpikir Kritis; Pemanasan Global

\begin{abstract}
:
This study aims to determine the increase in students' critical thinking skills by using discovery learning models on global warming material. This research was conducted in class VII at Taman Pemalang State Middle School 2 in the 2018/2019 academic year. Sampling research uses a multi-stage random sampling technique by taking two classes from the population for the control class and the experimental class. Data collection using test. The results showed that the experimental class that used the discovery learning model of critical thinking skills gained by students increased. This is shown from the increase in the percentage of students who initially $100 \%$ in the less critical category to $4 \%$ in the very critical category, $56 \%$ critical, $36 \%$ quite critical, and $4 \%$ less critical.
\end{abstract}

Keywords : Discovery Learning; Critical Thinking skills; Global Warming

\section{Pendahuluan}

Pendidikan merupakan suatu usaha sadar dalam proses mengubah tingkah laku maupun sikap seseorang melalui pengajaran dan pelatihan baik disekolah maupun diluar sekolah. Menurut (Depdiknas, 2003) pendidikan merupakan suatu usaha sadar dan terencana untuk mewujudkan suasana belajar dan proses pembelajaran agar siswa secara aktif mengembangkan potensi dirinya. Pembelajaran menjadi salah satu bagian dari dunia pendidikan. Pendidikan merupakansuatu proses interaksi peserta didik dengan sumber belajar pada suatu lingkungan belajar meliputi guru dan siswa yang saling bertukar informasi.

Novita Haryanti, Universitas Pancasakti Tegal nobitanian05@gmail.com

Antonius Tri Widodo, Universitas Pancasakti Tegal atwidodo@upstegal.ac.id

Yuni Arfiani, Universitas Pancasakti Tegal

yuniarfiani@upstegal.ac.id 
Menurut Daulae (2014) pembelajaran merupakan suatu proses yang dilakukan individu untuk mendapatkan suatu perubahan secara keseluruhan sebagai pengalaman diri sendiri dalam interaksi dengan lingkungannya, dari pendapat ini tidak heran jika pembelajaran juga menjadi salah satu bagian yang dapat mempengaruhi hasil belajar peserta didik. Hasil belajar merupakan salah satu tujuan yang akan dicapai dalam suatu pembelajaran disekolah baik berupa nilai maupun tingkah laku. Dalam dunia pendidikan mata pelajaran merupakan suatu hal yang sangat penting karena untuk memperoleh tujuan yang ingin dicapai dalam pendidikan. Mata pelajaran IPA menjadi salah satu bagian dari dunia pendidikan yang dapat berperan dalam melatih peserta didik mengembangkan keterampilan berpikir dan melatih tingkah laku atau sikap peserta didik untuk menghadapi perkembangan teknologi dan sains.

Hasil belajar merupakan hasil nyata yang diperoleh peserta didik setelah melakukan suatu proses belajar. Menurut Nurtanto dan Sofyan (2015) hasil belajar meliputi tiga ranah kemampuan, yaitu kognitif, afektif dan psikomotorik. Kemampuan dalam ranah kognitif diperoleh dari hasil tes yang diberikan kepada peserta didik, sedangkan psikomotorik atau keterampilan diperoleh dari sebarapa minatnya peserta didik dengan materi yang diajarkan seperti sikap kritis dan sikap ilmiah yang ditunjukan oleh peserta didik saat pelajaran berlangsung. Perolehan hasil belajar setiap peserta didik berbeda-beda dikarenakan ada faktor yang mempegaruhinya. Terdapat dua faktor yang dapat mempengaruhi hasil belajar yaitu faktor internal atau faktor yang berasal dari diri sendiri seperti perilaku, bakan, jasamani dan rohani. Faktor kedua yang mempengaruhi hasil belajar adalah faktor eksternal yang mana faktor ini berasal dari luar diri sendiri meliputi keluarga, sekolah, guru dan masyarakat (Slameto, 2010).

Guru menjadi salah satu bagian yang sangat penting dalam proses pembelajaran, dimana guru dapat mengatur proses berjalannya suatu kegiatan pembelajaran. Guru menjadi salah satu faktor eksternal yang mempengaruhi hasil belajar yang diperoleh peserta didik selama belajar di sekolah (Slameto, 2010). Berdasarkan penjelasan diatas maka dapat disimpulkan bahwa guru juga bisa menjadi penyebab kurang aktifnya peserta didik saat pembelajaran berlangsung. Seperti yang dikatakan Mureningsih (2014) kurang aktifnya peserta didik berperan dalam proses pembelajaran, diakibatkan karena kurang tepatnya guru dalam memilih model pembelajaran atau masih menggunakan cara konvensional, sarana prasarana, dan penggunaan media pembelajaran. Faktor tersebut yang menyebabkan rendahnya hasil belajar peserta didik baik kognitif maupun keterampilan berpikir kritis dan sikap ilmiah peserta didik. Keterampilan berpikir kritis dan sikap ilmiah dalam pembelajaran sangat di perlukan oleh peserta didik karena dapat memotivasi kegiatan belajar serta menunjukan seberapa minat peserta didik tersebut megikuti pembelajaran yang berlangsung. Melalui penanaman sikap ilmiah dalam belajar siswa memiliki kemungkinan untuk lebih dapat belajar memahami dan menemukan sehingga akan muncul kemampuan berpikir kritis pada peserta didik.

Berpikir merupakan ciri utama yang membedakan manusia dengan makhluk lainnya. Proses berpikir merupakan fitrah bagi manusia yang hidup. Kualitas hidup seseorang dapat ditentukan oleh bagaimana cara dia berpikir. Berpikir kritis didasari oleh pikiran yang bersifat terbuka, jelas, dan berdasarkan fakta (Harsanto, 2005). Peserta didik perlu mengasah keterampilan berpikir kritis dengan harapan mereka dapat membangun pemahaman dalam memaknai suatu kejadian. Menurut Purwanto, dkk (2012) keterampilan berpikir kritis sangat diperlukan karena apabila ada sesuatu keterangan yang tidak satau belum pasti hendaknya jangan dipercaya begitu saja. Sehingga peserta didik dapat membangun argumen dengan 
menggunakan bukti yang dapat dipercaya dan logika yang masuk akal. Peserta didik yang kurang memiliki keterampilan berpikir kritis akan berdampak pada rendahnya kesadaran terhadap cara pandang dan pemahaman terhadap suatu kejadian. Hal ini sejalan dengan pendapat Johnson (2007) yaitu dengan berpikir kritis, dapat membantu dalam memahami bagaimana memandang diri sendiri, bagaimana memandang dunia, dan bagaimana berhubungan dengan orang lain. Dengan ini peserta didik mampu mengambil keputusan atau kesimpulan dalam suatu kejadian dengan pemikiran yang rasional.

Dalam suatu pembelajaran yang aktif juga melibatkan peserta didik yang memuat berbagai komponen ketrampilan, salah satunya adalah berpikir kritis. Menurut Haryani (2011) berpikir kritis adalah suatu proses yang bertujuan untuk membuat keputusan rasional yang diarahkan untuk memutuskan apakah meyakini atau melakukan sesuatu. Berpikir kritis merupakan salah satu bagian dari berpikir tingkat tinggi, yang memiliki peranan signifikan dalam proses pembelajaran terutama pembelajaran IPA. Oleh karena itu, berpikir kritis diharapkan dapat dikuasai oleh peserta didik dalam proses pembelajaran. Indikator-indikator kemampuan berpikir kritis menurut Lestari dan Mohammad (2017) antara lain:

a. memberikan penjelasan sederhana

b. membangun keterampilan dasar

c. membuat simpulan

d. membuat penjelasan lebih lanjut

Kurikulum 2013 menuntut guru supaya melaksanakan pembelajaran saintifik dimana guru bisa sebagai sumber belajar, fasilitator, demonstrator, pembimbing dan motivator dalam pembelajaran. Pembelajaran yang baik yaitu pembelajaran dimana guru telah membuat sebuah rencana pelaksanaan pembelajaran (RPP) yang sesuai dengan kurikulum yang berlaku saat pembelajaran berlangsung. Menurut Nazarudin (2007) perangkat pembelajaran adalah suatu persiapan yang disusun guru dengan baik agar dalam pelaksanaan dan evaluasi pembelajaran dapat dilakukan secara sistematis dan memeperoleh hasil yang diinginkan.

Model pembelajaran merupakan kerangka konseptual yang melukiskan prosedur secara sitematis dalam mengorganisasikan pengalaman belajar untuk mencapai tujuan pembelajaran yang digunakan guru sebagai pedoman dalam aktivitas kegiatan belajar mengajar (Indrawati, 2011). Pemilihan model pembelajaran harus sesuai dengan karakteristik materi yang akan disampaikan agar dapat mencapai tujuan yang diinginkan. Penggunaan model pembelajaran IPA akan berbeda dengan model pembelajaran materi lain. Hal ini dikarenakan tidak semua model pembelajaran dapat digunakan semua materi pelajaran. Model pembelajaran yang diterapkan harus sesuai dengan kurikulum 2013 diantaranya yaitu, model pembelajaran inkuiri (Inquiry Based Learning), model pembelajaran discovery (Discovery Learning) dan model pembelajaran berbasis projek (Project Based Learning). Model pembelajaran ini digunakan oleh guru agar sesuai dengan kompetensi yang akan dicapai.

Model pembelajaran yang sesuai dengan materi IPA yaitu discovery learning, model pembelajaran ini menitikberatkan pada aktifitas siswa dalam pembelajaran (Lestari dan Yudhanegara, 2015). Keunggulan dari model discovery Learning yaitu, pembelajaran berpusat pada siswa akan tetapi guru juga berperan sama-sama aktif, hal ini searah dengan yang dikatakan Afandi dkk (2013) bahwa model pembelajaran discovery learning dapat meningkatkan keterlibatan peserta didik secara aktif. Keaktifan peserta didik dalam proses pembelajaran inilah yang dapat meningkatkan kemampuan berpikir kritis peserta didik dalam pembelajaran. 
Berdasarkan observasi yang telah dilakukan di SMP Negeri 2 Taman Pemalang, hasil belajar (kognitif) ipa kelas VII masih di bawah KKM. Data diperoleh dari nilai ulangan akhir semester 1 tahun 2018/2019. Kurang keterlibatannya peserta didik selama kegiatan pembelajaran menjadi salah satu alasan rendahnya hasil belajar yang diperoleh peserta didik karena keterampilan berpikir kritis yang dimiliki peserta didik masih rendah. Berdasarkan uraian masalah yang dijelaskan diatas, maka dilakukan penelitian tentang penerapan model discovery learning untuk meningkatan kemampuan berpikir kritis pada tema pemanasan global.

\section{Metode}

Penelitian ini dilaksanakan di SMP Negeri 2 Taman Pemalang tahun pelajaran 2018/2019, dengan populasi seluruh peserta didik kelas VIIA, VIIB, VIIC, VIID dan VIIE. Sampel yang dipilih dengan teknik multistage random sampling didapatan kelas VIIA sebagai kelas kontrol dan VIIB sebagai kelas eksperimen. Variabel bebas dalam penelitian ini adalah model discovery learning, sedangkan variabel terikat dalam penelitian ini adalah peningkatan keterampilan berpikir kritis peserta didik antara kelas eksperimen dengan kelas kontrol.

Penelitian ini adalah penelitian eksperimen dengan desain pre-test post-test control group. Sebelum diberi perlakuan, peserta didik melaksanakan pre-test untuk mengukur kondisi awal, kemudian untuk mengetahui perbedaan kondisi kelas setelah diberi perlakuan yaitu dengan memberikan post-test yang sebelumnya memastikan kedua kelas homogen pada kondisi awal. Instrumen penelitian ini diuji menggunakan uji validitas, reliabilitas dan tingkat kesukaran, sebelum digunaan untuk evaluasi. Soal evaluasi yang digunakan berupa soal uraian karena tes ini dapat mengukur kemampuan berpikir peserta didik.

Metode yang digunaan untuk penelitian ini adalah tes. Data dianalisis melalui dua tahap. Uji tahap awal adalah uji homogenitas populasi menggunakan uji levene dan uji normalitas menggunakan rumus shapiro wilk. Uji tahap akhir untuk mengetahui peningkatan kemampuan berpikir kritis peserta didik menggunakan uji t-test. Kemudian uji kriteria berpikir kritis digunakan untuk mengetahui tingkatan berpikir kritis anak dimulai dari kriteria sangat kritis sampai kurang kritis.

Untuk mengetahui kriteria keterampilan berpikir kritis peserta didik dilakukan uji analisis menggunakan rumus :

$$
x=\frac{\text { Jumlah skor yang diperoleh }}{\text { Jumlah skor maksimal }} \times 100 \%
$$

Kriteria kemampuan berpikir kritis adalah:

$81,25<x \leq 100$ : Sangat Kritis

$62,50<x \leq 81,25:$ Kritis

$42,75<x \leq 62,50$ : Cukup Kriti

$25,00<x \leq 42,75:$ Kurang Kritis

Uji peningkatan keterampilan berpikir kritis peserta didik menggunakan uji t-test. Uji ini untuk mengetahui apakah keterampilan berpikir kritis peserta didik pada kelas eksperimen lebih 
baik dari kemampuan berpikir kritis peserta didik kelas kontrol. Menurut sugiyono (2011) rumus yang digunakan

$$
t=\frac{M d}{\sqrt{\frac{\sum X d^{2}}{N(N-1)}}}
$$

Dengan Md menunjukkan mean dari perbedaan pre-test dengan post-test (post test - pre test), $\mathrm{Xd}$ menunjukkan deviasi masing-masing subjek ( $\mathrm{d}-\mathrm{Md}), \sum \mathrm{Xd}^{2}$ menunjukkan jumlah kuadrat deviasi dan $\mathrm{N}$ menunjukkan subjek pada sampel. Apabila nilai $t_{\text {hitung }}>t_{\text {tabel, }}$ maka ada peningkatan kemampuan berpikir kritis yang signifikan pada tema pemanasan global pada kelas eksperimen dari pada kelas kontrol.

\section{Hasil dan Pembahasan}

Sebelum pelaksanaan penelitian, dilakukan analisis tahap awal yang bertujuan untuk mengetahui kondisi awal populasi. Analisis tahap awal dilakukan uji homogenitas menggunakan uji levene. Data yang diperoleh nilai nilai signifikansi $0.060>0.05$ dengan nilai levene statistic sebesar 3.710 karena nilai signifikansi lebih besar dari 0.05 maka populasi mempunyai varians yang sama atau homogen.

Keterampilan berpikir kritis meliputi keterampilan dapat memberikan penjelasan sederhana, membangun keterampilan dasar, membuat simpulan dan membuat penjelasan lebih lanjut (Lestari dan Yudhanegara, 2017). Penilaian aspek tersebut untuk mengetahui keterampilan berpikir kritis siswa selama pembelajaran. Peningkatan jumlah peserta didik baik kelas eksperimen maupun kontrol dapat dilihat pada tabel 1.

Tabel 1. Hasil Keterampilan Berpikir Kritis Peserta didik

\begin{tabular}{|c|c|c|c|c|}
\hline \multirow{2}{*}{$\begin{array}{l}\text { Sub Materi } \\
\text { Pokok }\end{array}$} & \multirow{2}{*}{$\begin{array}{l}\text { Objek } \\
\text { Penelitian }\end{array}$} & \multirow{2}{*}{ Kategori } & \multicolumn{2}{|c|}{ Jumlah Peserta Didik } \\
\hline & & & Pre test & Post test \\
\hline \multirow{9}{*}{ 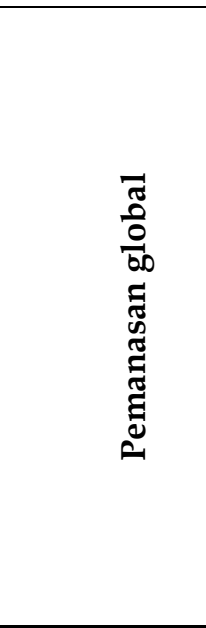 } & \multirow{5}{*}{ 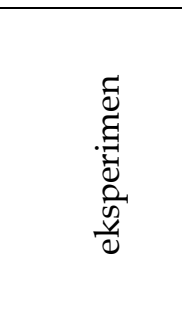 } & $\begin{array}{l}\text { Sangat } \\
\text { Kritis }\end{array}$ & - & 1 \\
\hline & & Kritis & - & 14 \\
\hline & & Cukup & - & 9 \\
\hline & & Kritis & - & 9 \\
\hline & & $\begin{array}{l}\text { Kurang } \\
\text { Kritis }\end{array}$ & 25 & 1 \\
\hline & \multirow{4}{*}{$\begin{array}{l}\overrightarrow{0} \\
\stackrel{\vec{t}}{\rightleftarrows} \\
\overrightarrow{0} \\
\dot{v}\end{array}$} & $\begin{array}{l}\text { Sangat } \\
\text { Kritis }\end{array}$ & - & - \\
\hline & & Kritis & 1 & 1 \\
\hline & & $\begin{array}{l}\text { Cukup } \\
\text { Kritis }\end{array}$ & 13 & 18 \\
\hline & & $\begin{array}{l}\text { Kurang } \\
\text { Kritis }\end{array}$ & 11 & 6 \\
\hline
\end{tabular}

Tabel 1 menunjukan jumlah peserta didik tiap kelas yang masuk kedalam setiap kategori keterampilan berpikir kritis. Kelas eksperimen pada pre test semua peserta didik dalam kategori kurang kritis setelah melalukan post-test terdapat 1 peserta didik yang ada pada kategori kurang kritis, 9 peserta didik dalam kategori cukup kritis, 14 dalam kategori kritis dan 1 peserta didik 
dalam ategori sangat kritis. Kenaikan jumlah peserta menunjukkan adanya peningkatan keterampilan berpikir kritis setelah dilakukan pembelajaran dengan model discovery learning. Hal ini berbeda dengan kelas kontrol jika dilihat pada tabel 1 kenaikan jumlah peserta didik tidak terlalu banyak dan hanya ada 1 peserta didik yang mencapai pada kategori kritis.

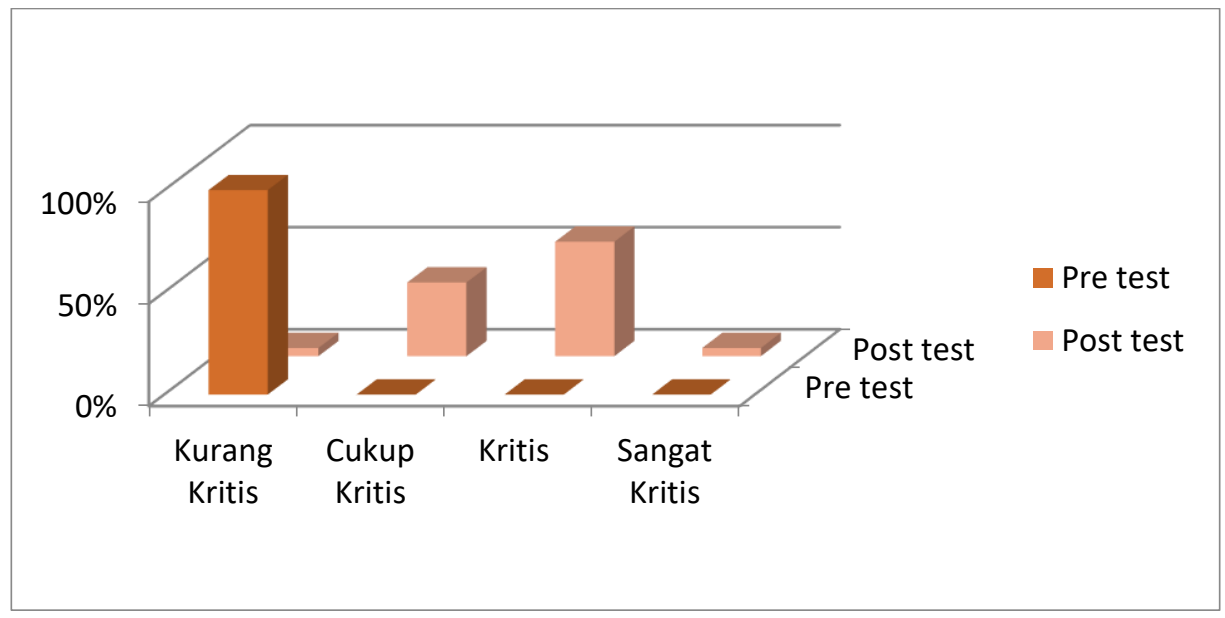

Grafik 1 Keterampilan Berpikir Kritis Kelas Eksperimen

Grafik 1 menunjukkan persentase jumlah peserta didik pada kelas eksperimen yang mencapai setiap kategori keterampilan berpikir kritis pada pre test dan post test. Pada pre test semua peserta didik dalam kategori kurang kritis namun meningkat pada post test menjadi $4 \%$ pada kategori kurang kritis, 36\% kategori kritis, 56\% kategori kritis dan 4\% dalam kategori sangat kritis.

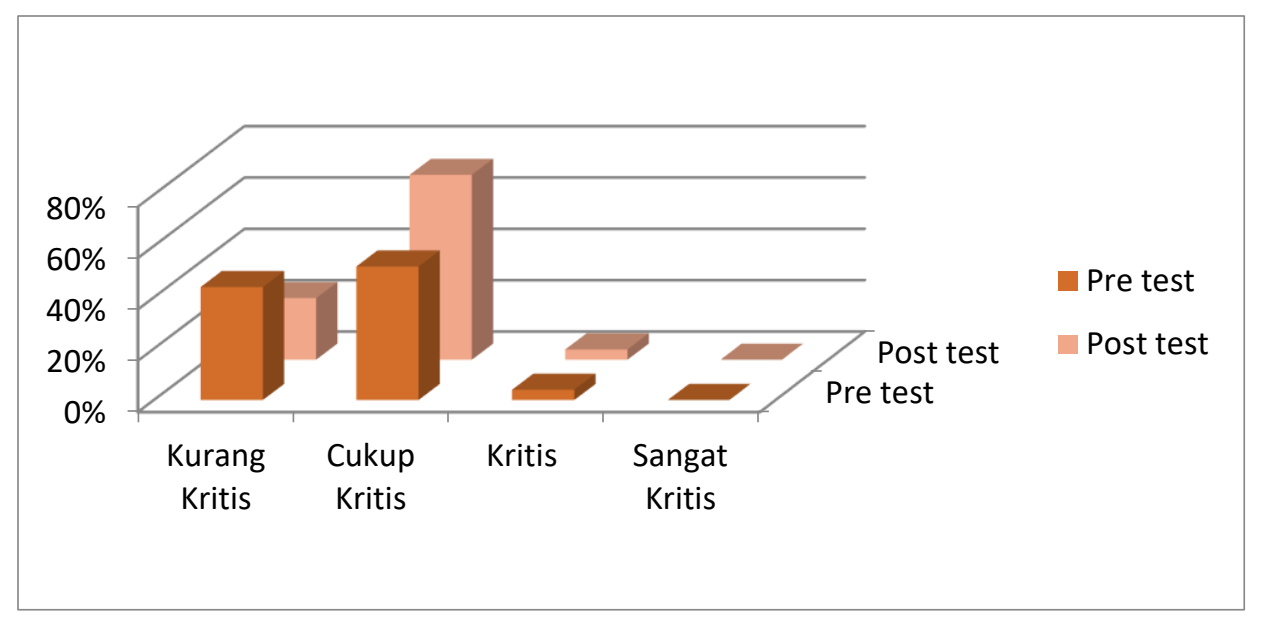

\section{Grafik 2 Keterampilan Berpikir Kritis Kelas Kontrol}

Grafik 2 menunjukkan persentse jumlah peserta didik pada kelas kontrol yang mencapai setiap kategori keterampilan berpikir kritis pada pre test dan post test. Pada pre test $44 \%$ peserta didik dalam kategori kurang kritis, 52\% kategori cukup kritis dan 4\% dalam kategori kritis. Meningkat pada post test menjadi $24 \%$ pada kategori kurang kritis, $72 \%$ kategori kritis dan $4 \%$ kategori kritis. Pada kelas kontrol hanya ada $4 \%$ yang mencapai kategori kritis dan tidak ada peserta didik yang mencapai kategori sangat kritis. 
Hasil keterampilan berpikir kritis peserta didik dalam penelitian ini pada saat pre-test rerata kelas eksperimen 32,9 dan kelas kontrol 44. Pada saat post-test hasil rerata kelas eksperimen 64,2 dan kelas kontrol 49,4. Hasil keterampilan bepikir kritis siswa mengalami peningkatan dari keadaan awal (pre-test) dan keadaan akhir (post-test) baik kelas eksperimen maupun kelas kontrol. Lebih jelasnya hasil keterampilan berpikir kritis dalam penelitian ini disajikan dalam Tabel 2.

Tabel 2 Keterampilan Berpikir Kritis Peserta Didik

\begin{tabular}{lcccc}
\hline Komponen & \multicolumn{2}{c}{ Eksperimen } & \multicolumn{2}{c}{ Kontrol } \\
\cline { 2 - 5 } & Pre test & Post test & Pre test & Post test \\
\hline $\begin{array}{l}\text { Mpeserta } \\
\text { didik }\end{array}$ & 25 & 25 & 25 & 25 \\
$\begin{array}{l}\text { Nilai } \\
\text { tertinggi }\end{array}$ & 42,5 & 87,5 & 62,5 & 62,5 \\
$\begin{array}{l}\text { Nilai } \\
\text { terrendah }\end{array}$ & 17,5 & 27,5 & 30 & 37,5 \\
$\begin{array}{l}\text { Rata-rata } \\
\text { Kategori }\end{array}$ & $\begin{array}{c}32,9 \\
\text { Kurang } \\
\text { Kritis }\end{array}$ & $\begin{array}{c}64,2 \\
\text { Kritis }\end{array}$ & $\begin{array}{c}44 \\
\text { Cukup } \\
\text { Kritis }\end{array}$ & $\begin{array}{c}\text { Cukup } \\
\text { Kritis }\end{array}$ \\
\hline
\end{tabular}

Tabel 2 menunjukkan rata-rata keterampilan berpikir kritis peserta didik mengalami peningkatan dari keadaan awal (pre-test) dan keadaan akhir (post-tes) baik kelas eksperimen maupun kelas kontrol. Peningkatan berpikir kritis peserta didik dapat diketahui dari hasil keadaan awal rata-rata berpikir kritis kelas eksperimen sebelum dan sesudah diberi pembelajaran dengan model pembelajaran discovery learning adalah sebesar 32,9 dan 64,2. Hasil keadaan awal rata-rata berpikir kritis kelas kontrol diketahui sebesar 44 dan rata-rata akhir 49,4. Hal ini menunjukkan hasil keterampilan berpikir kritis yang diperoleh peserta didik kelas eksperimen pada kondisi awal dalam kategori kurang kritis menjadi kategori kritis pada kondisi akhir. Sedangkan pada kelas kontrol pada kondisi awal dan akhir masih dalam kategori cukup kritis tidak ada peningkatan.

Tabel 3 Hasil Uji t Keterampilan Berpikir Kritis

\begin{tabular}{ccccc}
\hline Variabel & Kelas & Tt hitung & Tt tabel & PP value \\
\hline $\begin{array}{l}\text { Keterampilan } \\
\text { Berpikir Kritis }\end{array}$ & Kontrol & 55,320 & 11,708 & 00,000 \\
\cline { 2 - 5 } & Eksperimen & 116,876 & 11,708 & 00,000 \\
\hline
\end{tabular}

Tabel 3 menunjukan hasil analisis uji t yang diperoleh kelas eksperimen lebih besar dari kelas kontrol. Hal ini berarti terdapat peningkatan yang signifikan pada kelas eksperimen dari pada kelas kontrol. Peningkatan keterampilan berpikir kritis peserta didik pada kelas eksperimen atau yang menggunakan model discovery learning dikarenakan peserta didik terlibat langsung dalam kegiatan pembelajaran untuk mempelajari materi pemanasan global yang disajikan mulai dari diskusi, uji coba (praktium) maupun presentasi. Dengan ini mereka tentunya akan jauh lebih memahami materi, sehingga keterampilan peserta didik dalam 
mengidentifikasi masalah, mengevalusi, menyimpulkan dan mengemukakan pendapat jauh lebih tinggi. Keterlibatan peserta didik dalam kegiatan pembelajaran seperti ini tentunya akan membuat peserta didik menjadi lebih antusias, ingin tahu, tentang materi yang disajikan serta berpikiran terbuka selama kegiatan belajar. Hal ini sejalan dengan pendapat Santiyasa (2007:25), anak lebih mudah mempelajari hal yang konkret ketimbang yang bersifat abstrak. Pembelajaran fisika yang bersifat abstrak akan lebih mudah dipelajari ketika berawal dari sesuatu yang konkret atau nyata. Sedangkan pembelajaran pada kelas kontrol yang menggunakan model pembelajaran konvensional tentunya tidak memberikan dampak yang tinggi karena peserta didik tidak dilibatkan langsung dalam kegiatan pembelajaran.

Berbeda dengan kelas eksperimen, peningkatan keterampilan berpiir kritis peserta didik pada kelas kontrol tidak terlalu terlihat. Hal ini dapat dilihat dari rata-rata yang diperoleh peserta didik baik sebelum dan sesudah pembelajaran masih dalam kategori cukup kritis. Hal ini dikarenakan selama kegiatan pembelajaran peserta didik pada kelas kontrol hanya mendengarkan guru memberikan materi saja sehingga peserta didik menjadi pasif karena tidak teribat langsung dalam kegiatan pembelajaran.

Berdasarkan hasil pengamatan selama penelitian peserta didik kelas eksperimen yang menggunakan model pembelajaran discovery learning menunjukkan bahwa peserta didik terlibat langsung dalam kegiatan pembelajaran sehingga mereka lebih aktif, semangat dan antusias dalam kegiatan pembelajaran. Adanya pembagian kelompok untuk diskusi dan praktikum membuat peserta didik menjadi lebih senang dan dan tidak bosan dalam mengikuti kegiatan belajar. Hal ini juga mendorong peserta didik untuk berpikir dan bekerja atas inisiatif sendiri serta mengembangkan kecakapan individu sehingga dapat meningkatkan keterampilan berpikir kritis. Hal ini diperkuat oleh hasil penelitian Nugrahaeni, Amalia, dkk (2017:23) bahwa penerapan model discovery learning meningkatkan keterampilan berpikir kritis peserta didik ditunjukkan dari nilai persentase berpikir kritis peserta didik pada kriteria 80,57\% menjadi 88,5\%.

Sejalan dengan Lestari dan Yuhanegara (2015:63) yang mengatakan bahwa model pembelajaran discovery learning merupakan suatu model pembelajaran yang menitikberatkan pada aktifitas peserta didik dalam belajar. Sehingga selama pembelajaran peserta didik dilibatkan dalam kegiatan baik diskusi, percobaan langsung (praktikum) dan presentasi didepan kelas. Penerapan model discovery learning tepat diterapkan untuk menjelaskan materi pemanasan global. Hal ini karena banyak permasalahan yang berkaitan dengan pemanasan global yang dapat dijadikan sebagai bahan diskusi peserta didik. apabila peserta didik kurang memahami materi saat kegiatan diskusi, peserta didik diberikat kesempatan untuk bertanya dengan ini peserta didik menjadi lebih aktif dalam bertanya. Dalam kegiatan praktikum peserta didik juga dituntut untuk bisa kerjasama dengan teman kelompoknya, kegiatan seperti ini dapat menjadikan peserta didik menjadi lebih mandiri dalam mengambil keputusan ataupun menyimpulkan suatu kegiatan sesuai dengan fakta-fakta yang telah didapat dari kegiatan praktikum. Dalam kegiatan presentasi peserta didik dapat mengungkapkan pendapatnya dan mengajukan pertanyaan maupun sanggahan sehingga mereka lebih aktif dalam kegiatan pembelajaran. Hal ini sejalan dengan pendapat Afandi dkk (2013:99) yang mengatakan bahwa model pembelajaran discovery learning memiliki kelebihan yaitu melatih peserta didik belajar mandiri sehingga dapat berperan aktif dalam kegiatan belajar untuk mencapai tujuan pembelajaran bersama. 
Penggunaan model pembelajaran discovery learning bagi peserta didik kelas VII SMP Negeri 2 Taman Pemalang merupakan suatu hal yang baru. Sehingga saat pelaksanaan pembelajaran pertama peserta didik masih malu atau kurang percaya diri akan kemampuannya. Akan tetapi pada pertemuan selanjutnya peserta didik mulai aktif dalam kegiatan pembelajaran untuk memahami materi yang diperolehnya. Keaktifan peserta didik ditunjukan oleh mulai banyak peserta didik yang bertanya materi yang disajikan.

Kegiatan penelitian ini juga tidak lepas dari hambatan yang dialami oleh peneliti saat penelitian. Berkaitan dengan kesiapan peserta didik penerapan model discovery learning pada kelas discovery learning masih membuat peserta didik merasa malu karena tidak terbiasa menggunakan model pembelajaran tersebut yang menggelompokkan peserta didik dalam kegiatan pembelajaran. Dilihat dari waktu pembelajaran, penerapan model discovery learning membutuhkan waktu yang cukup banyak untuk mengatur anggota kelompok dalam kegiatan praktikum maupun diskusi.

Penerapan model discovery learninng dapat dilakukan dengan maksimal apabila guru dalam kegiatan pembelajaran lebih memahami model pembelajaran yang digunakan sesuai dengan materi yang akan diajarkan. Guru juga perlu membagi berapa lama waktu yang dibutuhkan dalam setiap kegiatan yang akan dilakukan, sehingga waktu yang disediakan cukup untuk kegiatan yang akan dilaksanakan sehingga lebih efisien.

\section{Simpulan}

Berdasarkan analisis hasil penelitian dan pembahasan dapat disimpulkan bahwa penerapan model discovery learning pada tema pemanasan global dapat meningkatkan keterampilan berpikir kritis peserta didik. Hal ini dapat dilihat dari rata-rata yang diperoleh kelas eksperimen pada pre tes dan post test yaitu sebesar 32,9 menjadi 64,2 dari kategori keterampilan berpikir kritis yang diperoleh peserta didik kurang kritis menjadi kategori kritis. Peningkatan keterampilan berpikir kritis peserta didik dikarenakan keterlibatan peserta didik selama kegiatan pembelajaran, yang membuat peserta didik menjadi senang dan tidak bosan dalam mengikuti kegiatan pembelajaran. Berbeda dengan kelas kontrol yang memberoleh rata-rata masih dalam kategori cukup kritis. Hal ini dikarenakan pada kelas kontrol peserta didik tidak dilibatkan langsung dalam kegiatan pembelajaran, mereka hanya mendengarkan dan menulis materi yang disampaikan oleh guru saja.

\section{Daftar Rujukan}

Afandi, muhamad dkk. 2013. Model dan Metode Pembelajaran di Sekolah. Semarang: Unissula press

Departemen Pendidikan Nasional. 2003. Undang-Undang Republik Indonesia No. 20 Tahun 2003 Tentang Sistem Pendidikan Nasional. Jakarta: Depdiknas

Daulae, Tatta Herawati. 2014. Menciptakan Pembelajaran yang Efektif. Jurnal Iain Padang Sidimpuan. Vol. 6(2). Hal:131-150 
Haryani, Desti. 2011. Pembelajaran Matematika Dengan Pemecahan Masalah untuk Menumbuhkembangkan Kemampuan Berpikir Kritis Siswa. Prosiding Seminar Nasional Penelitian, Pendidikan dan Penerapan MIPA. 1980:121-126

Indrawati. 2011. Model-Model Pembelajaran. Jember: Universitas Jember

Lestari, K. E dan Yudhanegara, M. D. 2015. Penelitian Pendidikan Matematika. Bandung: PT Refika Aditama

Mureningsih, Endang S. 2014. Meningkatkan Hasil Belajar Siswa Melalui Media Pembelajaran Multimedia Interaktif. Jurnal Madaniyah. Edisi VII: 215

Nazarudin. 2007. Manajemen Pembelajaran : Implementasi, Konsep, Karakteristik, Metodologi Pendidikan Agama Islam di Sekolah Umum. Yogyakarta: Teras

Nugrahaeni, Amelia. 2017. Penerapan Model Pembelajaran Discovery Learning Untuk Meningkatkan Kemampuan Berpikir Kritis dan Hasil Belajar Kimia. Jurnal Pendidikan Kimia Indonesia. Vol. 1(1). Hal. 23-29

Nurtanto, Muhammad dan Sofyan Herminarto. 2015. Implementasi Problem Based Learning Untuk Meningkatkan Hasil Belajar Kognitif, Psikomotor dan Afektif Siswa SMK. Jurnal Pendidikan Vokasi. Vol. 5(3). Hal. 352-364

Purwanto, Candra Eko, dkk. 2012. Penerapan model pembelajaran gided discovery pada materi pemantulan cahaya untuk meningkatkan keterampilan berpikir kritis. Jurna pendidikan fisika unnes. Vol. 1(1). Hal: 26-32

Santyasa, I.W. 2007. Landasan Konseptual Media Pembelajaran. Makalah. Universitas Pendidikan Ganesha.

Slameto. 2010. Belajar dan Faktor-Faktor Yang Mempengaruhinya. Jakarta: PT Rineka Cipta

Sugiyono. 2011. Metode Penelitian Kuantitatif Kualitatif dan RED. Bandung: Alfabeta 